\title{
Performance Comparison of Solar Still With Inbuilt Condenser and Agitator Over Conventional Solar Still With Energy and Exergy Analysis
}

\section{Arun Kumar Rajasekaran}

Ramco Institute of Technology

Kalidasa Murugavel Kulandaivelu ( $\nabla$ kali_vel@rediffmail.com )

National Engineering College https://orcid.org/0000-0002-0179-4135

\section{Research Article}

Keywords: Solar still, Desalination, Inbuilt Condenser, Agitator, Exergy, Energy

Posted Date: February 28th, 2022

DOI: https://doi.org/10.21203/rs.3.rs-1285688/v1

License: (c) (1) This work is licensed under a Creative Commons Attribution 4.0 International License.

Read Full License 


\section{Abstract}

Water plays a vital role in defending the contagious diseases globally, leading to continual increase in demand of water. The increase in demand in turn reduces the fresh water availability. To meet this water demand desalination technologies can be used for fresh water production from seawater. Passive solar distillation techniques are the simplest and favourable, as they use sustainable renewable solar energy as a source. Rate of evaporation and rate of condensation are the major influencing factors which have a direct impact on distillate yield. Single basin single slope conventional solar still (CSS) and single basin single slope solar still with inbuilt condenser and agitator (SSICA) were designed and fabricated for the current study. Both the stills were tested under same ambient condition to compare the performance. Through experimental results, it was found that SSICA had $98.69 \%$ more productivity than CSS. The agitating effect caused by agitator in SSICA led to increase in rate of evaporation. The increase in condensing area for same evaporation area of SSICA improved the condensation rate. These two synergized effects resulted in overall performance improvement of SSICA over CSS. Energy analysis revealed that SSICA is $24.42 \%$ more efficient than CSS. Exergy efficiency of SSICA and CSS were calculated as $4.82 \%$ and $2.04 \%$ respectively.

\section{Introduction}

Demand for fresh water increases exponentially day by day. In spite of being primary need, accessibility to potable water has become a challenge as the population of the world increases. The United Nations High Level Political Programme on Sustainable Development took 'Water and Sanitation' as the theme for the year 2018 and reports that over 2 billion people across the world are experiencing high water stress. Though $70 \%$ of earth surface is covered with water, humans are not able to access fresh water (ElSamadony and Kabeel, 2014). Basin type solar still is one among the promising technologies that can address the water scarcity. The problem associated with solar still is its least productivity. The productivity of solar stills is influenced by various parameters (Muftah et al., 2014, Prakash et al., 2015, Sharshir et al., 2016). Improving rate of evaporation and rate of condensation increases the distillate production in a solar still. Researchers across world progress in improving the productivity of passive and active solar stills by adopting different techniques that influences the rate of evaporation and rate of condensation of solar stills (Manokar et al., 2014). Singh et al., (2021) reviewed the design, operational and environmental characteristics on solar still performance. Performance enhancement techniques associated with new designs and modifications in a passive solar still were reviewed by Mohsenzadeh et al., (2021). The new designs were reviewed based on four processes and individual effects of each component's designs were discussed. Shoeibi et al., (2021) reviewed the techniques adopted for improving evaporation rate and condensation rate simultaneously.

Use of nano particles (Iqbal et al., 2021), wick type solar stills (Jobrane et al., 2020), improves the rate of evaporation reasonably. Among various efforts, introducing agitation effects to the saline water is having promising effects on rate of evaporation. Experimentation works on introducing agitation effect to basin water have proven increase in rate of evaporation. Kumar et al., (2016) compared the performance of 
conventional solar still and still with agitation effect and external condenser. The combined effects led to $39.49 \%$ more distillate yield in modified still over conventional solar still. Omara et al., (2017) investigation reports that use of water fan had improved the distillate yield due to increase in rate of evaporation. Essa et al., (2020) have done an experimental study on solar stills with flat and corrugated rotating discs at varying speeds which provided greater areal extent for evaporation. A higher distillate output of $124 \%$ was associated with corrugated discs with wick. Amongst the various integrations to conventional solar stills to improve its performance, Younis et al., (2020) had used a rotating drum within the conventional still to improve the yield. Based on comparison, system with smooth drum and system with rough drum had an improved yield by $198 \%$ and $431.1 \%$ respectively over the system without drums. The factors favouring the yield are rough surface, increased radius to length ratio, increased angular speed of rotation of drum.

Increasing the condensing area will also have direct impact on solar still performance. The different techniques to improve the performance of enhanced condensation area in a solar still were reviewed by Patel and Modi reviewed (2020). Inclusion of a fan inside the still can improve evaporation rate by $25 \%$ and improved area of condensation had notable impact on productivity (Nayi and Modi 2018). Inclusion of external condenser along with rotating drum and carbon nano particles have increased productivity by $350 \%$ over conventional still at $0.1 \mathrm{rpm}$ speed (Abhullah et al., 2019). Addition of inbuilt condenser is one of the methods to improve the rate of condensation.

The performance of solar stills can be assessed using various models including mathematical modelling and theoretical modelling. Energy and exergy analysis gives a clear picture about the effectiveness of the solar still. Many researchers have carried out both energy and exergy analysis for the respective experimental set-ups. For a better accuracy in results, studies on solar still were conducted only during summer. Amiri et al., (2021) studies proven that high temperature of ambient are conducive for energy efficiency and cold temperature of ambient is conducive for exergy efficiency. A theoretical performance analysis of a single slope passive solar still for energy and exergy models was carried out by Yousef et al., (2017). Sharshir et al. (2020) and (2018) analyzed the energy and exergy performance of solar still integrated carbon black and copper oxide nanoparticles. Energy, exergy and economic aspects of a solar still with composite material heat storage was analysed by Kabeel et al., (2019) and Mevada et al., (2021) investigated for solar still with energy storage materials. Dumka et al., (2020) and (2018), too carried out energy and exergy analysis. It has been observed that maximum exergy destruction is with basin of solar still.

Through above literature survey, it was evident that improving rate of evaporation by agitation will impact on the higher yield of distillate. Increase in area of condensation for same evaporation area will improve the rate of condensation and in turn the productivity. Energy and exergy analysis will help to understand the exergy destruction and analyze the scope for improvement aspects in future works. All these findings are implemented in the present work.

\section{Experimentation}


A single basin single slope conventional solar still (CSS) and a modified solar still whose performances are to be compared were fabricated. The modified still was designed with an inbuilt condenser and an agitator to agitate the basin water. The modified still is called as solar still with in-built condenser and agitator (SSICA). Both the stills were fabricated with the same absorber area of $0.25 \mathrm{~m}^{2}(500 \times 500 \mathrm{~mm})$ using galvanized iron of $1.5 \mathrm{~mm}$ thickness. The lower end of both stills was designed at $100 \mathrm{~mm}$ height and the higher end of SSCIA was kept at $245 \mathrm{~mm}$ with $30^{\circ}$ of inclination. Inbuilt condenser area of modified still is $0.125 \mathrm{~m}^{2}(250 \times 500 \mathrm{~mm})$. SSICA is attached with an agitator coupled with a DC motor and a solar PV panel of area $0.03 \mathrm{~m}^{2}(200 \times 150 \mathrm{~mm})$ which helps the agitator to agitate the surface water. Stills were painted black inside to ensure maximum absorptivity. $25 \mathrm{~mm}$ thick thermocol is fixed on all side walls and the bottom of both stills to minimize the heat loss. Figure 1a \& $1 \mathrm{~b}$ shows the schematic of CSS and SSICA respectively used in this work. Figure 2 shows the experimental setup used for the study. Both stills were tested under same ambient conditions. Experimentation was carried out at Ramco Institute of Technology, Rajapalayam, India $\left(9.4536^{\circ} \mathrm{N}, 77.5433^{\circ} \mathrm{E}\right)$ between 9:00AM to 5:00PM during sunny days in the month of June 2021 . Water levels were maintained at $10 \mathrm{~mm}$ depth in both the stills. Temperatures of basin, basin water, glass cover and atmosphere were measured along with solar intensity for every hour of experimentation period. The accuracy, range and error limits of the instruments used are presented in Table 1.

Table 1

Accuracy and error limits for various measuring instruments

\begin{tabular}{|lllll|}
\hline SI. No. & Instrument & Accuracy & Range & \%Error \\
\hline 1 & Temperature indicator & $+1{ }^{\circ} \mathrm{C}$ & $0-100{ }^{\circ} \mathrm{C}$ & $0.25 \%$ \\
2 & Thermocouple & $+0.1^{\circ} \mathrm{C}$ & $0-100^{\circ} \mathrm{C}$ & $0.5 \%$ \\
3 & PV type sun meter & $+1 \mathrm{~W} / \mathrm{m}^{2}$ & $0-2,500 \mathrm{~W} / \mathrm{m}^{2}$ & $2.5 \%$ \\
\hline 4 & Measuring jar & $+10 \mathrm{ml}$ & $0-1000 \mathrm{ml}$ & $5 \%$ \\
\hline
\end{tabular}

\section{Energy And Exergy Analysis Of Solar Still Components}

Exergy destruction of basin, basin water and glass cover were analysed for both CSS and SSICA in the current work. The formulae used for energy and exergy analysis [Equation 1 to 18] are given below (Vaithilingam S et al. 2021). The hourly measured solar intensity, basin temperature, basin water temperature, glass cover temperature and distillate yield for the experimental area during experimentation period was taken for energy and exergy calculations. The total energy in and total energy out vested in the respective stills were equated for calculating energy performance. The total exergy in and total exergy out vested in each component was equated for exergy destruction calculations of each component

\subsection{Energy analysis of passive solar still:}




$$
\eta_{\text {energy }}=\frac{m_{W} * L}{\left(A_{s} * \sum I_{t} * 3600\right)}
$$

1

\subsection{Exergy analysis of passive solar still:}

$$
\sum \dot{E}_{X_{\text {sun }}}-\sum \dot{E}_{X_{\text {evap }}}=\sum \dot{E}_{X_{\text {dest }}}
$$

2

$$
\sum \dot{E}_{X_{\text {sun }}}=\left(\left(A_{s} * \sum I_{t}\right)\right) *\left\lfloor 1-\frac{4}{3} *\left(\frac{T_{a}+273}{T_{s}}\right)+\frac{1}{3} *\left(\frac{T_{a}+273}{T_{s}}\right)^{4}\right\rfloor
$$

3

$$
\sum \dot{E}_{X_{\text {evap }}}=\frac{m_{W} * L *\left[1-\left(\frac{T_{a}+273}{T_{W}+273}\right)\right]}{3600}
$$

4

$$
\eta_{E X}=1-\frac{\dot{E}_{X_{\text {dest }}}}{\dot{E}_{X_{\text {sun }}}}
$$

5

\subsection{Exergy analysis of three main components:}

The exergy analysis of three major components of the still - basin, saline water and glass cover were carried out individually.

3.3.1 Basin

$$
\mathrm{E}_{\mathrm{x}_{\text {des. }, \mathrm{b}}}=\left(\tau_{\mathrm{g}} \tau_{\mathrm{w}} \alpha_{\mathrm{b}}\right) \mathrm{E}_{\mathrm{x}_{\text {sun }}}-\left(\mathrm{E}_{\mathrm{x}_{\mathrm{w}}}+\mathrm{E}_{\mathrm{x}_{\text {ins. }}}\right)
$$

6

$$
\mathrm{E}_{\mathrm{x}_{\text {sun }}}=\mathrm{I}_{\mathrm{t}}\left[1+\frac{1}{3}\left(\frac{\mathrm{T}_{\mathrm{a}}}{\mathrm{T}_{\mathrm{s}}}\right)^{4}-\frac{4}{3}\left(\frac{\mathrm{T}_{\mathrm{a}}}{\mathrm{T}_{\mathrm{s}}}\right)\right]
$$




$$
\mathrm{E}_{\mathrm{x}_{\mathrm{w}}}=\mathrm{h}_{\mathrm{w}}\left(\mathrm{T}_{\mathrm{b}}-\mathrm{T}_{\mathrm{w}}\right)\left(1-\frac{\mathrm{T}_{\mathrm{a}}}{\mathrm{T}_{\mathrm{b}}}\right)
$$

8

$$
\mathrm{E}_{\mathrm{x}_{\text {ins. }}}=\mathrm{h}_{\mathrm{b}}\left(\mathrm{T}_{\mathrm{b}}-\mathrm{T}_{\mathrm{a}}\right)\left(1-\frac{\mathrm{T}_{\mathrm{a}}}{\mathrm{T}_{\mathrm{b}}}\right)
$$

9

\subsubsection{Saline Water}

$$
\mathrm{E}_{\mathrm{x}_{\text {des }, \mathrm{w}}}=\left(\tau_{\mathrm{g}} \alpha_{\mathrm{w}}\right) \mathrm{E}_{\mathrm{x}_{\text {sun }}}+\mathrm{E}_{\mathrm{x}_{\mathrm{w}}}-\mathrm{E}_{\mathrm{x}_{\mathrm{t}, \mathrm{w}-\mathrm{g}}}
$$

10

$$
E_{x_{t, w-g}}=E_{x_{e, w-g}}+E_{x_{c, w-g}}+E_{x_{r w-g}}
$$

11

$$
\mathrm{E}_{\mathrm{x}_{\mathrm{e}, \mathrm{w}-\mathrm{g}}}=\mathrm{h}_{\mathrm{e}, \mathrm{w}-\mathrm{g}}\left(\mathrm{T}_{\mathrm{w}}-\mathrm{T}_{\mathrm{gi}}\right)\left(1-\frac{\mathrm{T}_{\mathrm{a}}}{\mathrm{T}_{\mathrm{w}}}\right)
$$

12

$$
\mathrm{E}_{\mathrm{x}_{\mathrm{c}, \mathrm{w}-\mathrm{g}}}=\mathrm{h}_{\mathrm{c}, \mathrm{w}-\mathrm{g}}\left(\mathrm{T}_{\mathrm{w}}-\mathrm{T}_{\mathrm{gi}}\right)\left(1-\frac{\mathrm{T}_{\mathrm{a}}}{\mathrm{T}_{\mathrm{w}}}\right)
$$

13

$$
\mathrm{E}_{\mathrm{x}_{\mathrm{r}, \mathrm{w}-\mathrm{g}}}=\mathrm{h}_{\mathrm{r}, \mathrm{w}-\mathrm{g}}\left(\mathrm{T}_{\mathrm{w}}-\mathrm{T}_{\mathrm{gi}}\right)\left[1+\frac{1}{3}\left(\frac{\mathrm{T}_{\mathrm{a}}}{\mathrm{T}_{\mathrm{w}}}\right)^{4}-\frac{4}{3}\left(\frac{\mathrm{T}_{\mathrm{a}}}{\mathrm{T}_{\mathrm{w}}}\right)\right]
$$

14

3.3.3 Glass Cover

$$
\mathrm{E}_{\mathrm{x}_{\text {des. }, \mathrm{g}}}=\alpha_{\mathrm{g}} \mathrm{E}_{\mathrm{X}_{\text {sun }}}+\mathrm{E}_{\mathrm{x}_{\mathrm{t}, \mathrm{w}-\mathrm{g}}}-\mathrm{E}_{\mathrm{x}_{\mathrm{t}, \mathrm{g}-\mathrm{a}}}
$$




$$
E_{x_{t, g-a}}=E_{x_{c, g-a}}+E_{x_{r, g-a}}
$$

16

$$
\mathrm{E}_{\mathrm{x}_{\mathrm{c}, \mathrm{g}-\mathrm{a}}}=\mathrm{h}_{\mathrm{c}, \mathrm{g}-\mathrm{a}}\left(\mathrm{T}_{\mathrm{go}}-\mathrm{T}_{\mathrm{a}}\right)\left(1-\frac{\mathrm{T}_{\mathrm{a}}}{\mathrm{T}_{\mathrm{go}}}\right)
$$

17

$$
\mathrm{E}_{\mathrm{x}_{\mathrm{r}, \mathrm{g}-\mathrm{a}}}=\mathrm{h}_{\mathrm{r}, \mathrm{g}-\mathrm{a}}\left(\mathrm{T}_{\mathrm{go}}-\mathrm{T}_{\mathrm{a}}\right)\left[1+\frac{1}{3}\left(\frac{\mathrm{T}_{\mathrm{a}}}{\mathrm{T}_{\mathrm{go}}}\right)^{4}-\frac{4}{3}\left(\frac{\mathrm{T}_{\mathrm{a}}}{\mathrm{T}_{\mathrm{go}}}\right)\right]
$$

\section{Results And Discussion}

The temperatures of basin, basin water, glass cover and atmosphere along with solar intensity, distillate yield were measured and were analyzed for the performance study. Overall energy and exergy study of each major component helped in analysing the exergy destruction vested in each component which gives the scope for improvement further. The experimental results are presented below.

Trend of ambient temperature and solar intensity along the day of experimentation is shown in figure 3 . The experimental values of solar intensity were found closer to average solar radiation of the geographic area. The maximum solar radiation falls between 12PM to 2PM. Peak value of solar intensity was recorded as $793 \mathrm{~W} / \mathrm{m}^{2}$ at $1 \mathrm{PM}$. As the Sun's radiation falls almost perpendicular to earth's surface, peak value was recorded at $1 \mathrm{PM}$. Similarly, the ambient temperature attains its peak value $\left(38^{\circ} \mathrm{C}\right)$ at $2 \mathrm{PM}$. As the earth re-radiates the absorbed heat during post noon, the maximum temperature falls around 2PM.

Figure 4 shows cumulative yield of SSICA and CSS which were $4.856 \mathrm{~L} / \mathrm{m}^{2} /$ day and $2.44 \mathrm{~L} / \mathrm{m}^{2} /$ day respectively. Improvement in productivity of SSICA over CSS is due to agitator and introduction of inbuilt condenser. Introduction of inbuilt condenser increased the area of condensation for same absorber area. This led to increase in rate of condensation and in turn increase in productivity. Agitation effect caused by agitator increased surface area of contact with surrounding air by forming waves. This led to increase in evaporation rate. Further, stirring effect stimulates movement of water molecules along depth of saline water which may also be the factor for increase in evaporation rate. This increase in evaporation rate, accounted in improvement of distillate yield. It was founded that the maximum hourly yield of both the stills were between 12PM to 3PM as the Sun's radiation was maximum during that time. 
The temperatures of saline water and glass cover in both CSS and SSICA were measured and are presented in figure 5 with respect to time. The maximum temperature of saline water for CSS and SSICA were $64^{\circ} \mathrm{C}$ and $72^{\circ} \mathrm{C}$ respectively. Saline water of both the stills registered their maximum temperature at 2PM during which the basin temperature was also at its peak. The reason for attainment of peak value around 2PM could be the diffusion of heat from the absorber plate surface, after the solar intensity began to decrease around 1PM after reaching its peak value. The highest glass cover temperature recorded in CSS and SSICA were $62^{\circ} \mathrm{C}$ and $66^{\circ} \mathrm{C}$ respectively. The glass temperature values of SSICA are higher than the glass temperature values of CSS after attaining its peak temperature. This reflection can be due to more rejection of latent heat from vapour to glass cover in SSICA when compared to CSS.

Energy and exergy efficiency of CSS and SSICA is compared in figure 6. SSICA comparison is made by including and excluding the solar PV area. The energy and exergy efficiency of CSS were calculated as $31.25 \%$ and $2.04 \%$ respectively. The values of the same for SSICA by including the solar PV area are computed as $55.67 \%$ and $4.31 \%$. By neglecting the solar PV area, the energy and exergy efficiencies of SSICA were found as $62.34 \%$ and $4.82 \%$ respectively. The agitator in SSICA is powered through solar PV which also an absorber with an area of $0.03 \mathrm{~m}^{2}$. By considering the solar PV area, the energy and exergy efficiencies of SSICA are $24.42 \%$ and $2.28 \%$ more than CSS respectively. Considering the absorber area solar PV, gives more optimistic comparison between the stills. The combined effects of agitator and inbuilt condenser led to increase in energy and exergy efficiencies of SSICA over CSS.

Basin exergy destruction of CSS and SSICA for every hour is plotted in figure 7. The destruction of exergy in CSS and SSICA attains its maximum at 1PM respectively. Peak values were calculated as $525.45 \mathrm{~W} / \mathrm{m}^{2}$ and $505.748 \mathrm{~W} / \mathrm{m}^{2}$ respectively for CSS and SSICA. Basin exergy destruction of SSICA is minimum than CSS during most of the time. This indicates that, the agitation effect in SSICA had paved way for more energy transfer from basin to saline water than in CSS, leading to increase in productivity of distillate. The total exergy destruction of SSICA and CSS are $3044.68 \mathrm{~W} / \mathrm{m}^{2}$ and $3132.71 \mathrm{~W} / \mathrm{m}^{2}$ respectively.

Figure 8 pictures the exergy destruction of saline water of both the stills. The peak destruction of the stills was found around 1PM of the day. The exergy destruction at $1 \mathrm{PM}$ is calculated as $48.259 \mathrm{~W} / \mathrm{m}^{2}$ and $50.44 \mathrm{~W} / \mathrm{m}^{2}$ for SSICA and CSS respectively. As the solar intensity is maximum at $1 \mathrm{PM}$, the total input energy available to the saline water at the time is maximum and thus the exergy destruction reaches peak around 1PM for both the stills. Exergy destruction sees a change in trend in after 2PM in which destruction in SSICA is more than CSS. The total exergy destruction of water in SSICA and CSS is 314.42 $\mathrm{W} / \mathrm{m}^{2}$ and $326.93 \mathrm{~W} / \mathrm{m}^{2}$ respectively.

Exergy destruction of glass covers in SSICA and CSS is figured in figure 9, which reached their respective peak value $48.72 \mathrm{~W} / \mathrm{m}^{2}$ and $40.15 \mathrm{~W} / \mathrm{m}^{2}$ close to $2 \mathrm{PM}$. The total exergy destruction of SSICA and CSS were calculated as $215.24 \mathrm{~W} / \mathrm{m}^{2}$ and $210.52 \mathrm{~W} / \mathrm{m}^{2}$. As the productivity of SSICA is maximum than CSS, the heat gained by the glass through latent heat from vapour will be more. Thus, total exergy destruction of SSICA is greater than CSS. 
Total exergy destruction of solar still components basin, water and glass are shown in figure 10. It can be seen that the maximum exergy destruction is seen in basin of solar stills when compared to the others. Basin is the prime receiver of input solar energy in a solar still. As only a minimal portion of received energy is converted as useful energy, the destruction is maximum in basin. Agitation effect which led to increase in evaporation rate had reduced the exergy destruction in basin and water of SSICA. From the graph, it is evident that working on decreasing the exergy destruction in basin will help in improving the productivity of solar still.

Through exergy destruction analysis, it is evident that the destruction in exergy lies maximum with basin. Improvements ensuring decrease in exergy destruction in basin can lead to performance improvement in solar still. Few efforts taken in increasing the performance of solar still is presented in Table 1 and the same is compared with present work. 
Table 1

Comparison between the productivity for various evaporation and condensation improvement techniques

SI. Author name Type of solar still

Enhancement techniques

Productivity

No.

\begin{tabular}{|c|c|c|c|c|}
\hline \multirow[t]{2}{*}{1} & \multirow{2}{*}{$\begin{array}{l}\text { (Attia et al. } \\
2021 a)\end{array}$} & \multirow{2}{*}{$\begin{array}{l}\text { Single slope solar still with } \\
\text { energy storage material }\end{array}$} & - conventional still & $3.80 \mathrm{~kg} / \mathrm{m}^{2}$ \\
\hline & & & - solar still with ESM & $5.27 \mathrm{~kg} / \mathrm{m}^{2}$ \\
\hline \multirow[t]{2}{*}{2} & \multirow{2}{*}{$\begin{array}{l}\text { (Attia et al., } \\
2021 b)\end{array}$} & \multirow{2}{*}{$\begin{array}{l}\text { Hemispherical and single- } \\
\text { slope solar still }\end{array}$} & - Single-slope solar still & $3.64 \mathrm{~L} / \mathrm{m}^{2}$ \\
\hline & & & - Hemispherical still & $5.38 \mathrm{~L} / \mathrm{m}^{2}$ \\
\hline \multirow[t]{2}{*}{3} & \multirow{2}{*}{$\begin{array}{l}\text { (Dubey and } \\
\text { Mishra 2021) }\end{array}$} & \multirow{2}{*}{$\begin{array}{l}\text { Double slope solar still } \\
\text { augmented with dye, pebbles } \\
\text { and metal chips }\end{array}$} & - Double slope solar still & $1.567 \mathrm{~kg}$ \\
\hline & & & $\begin{array}{l}\text { - Modified double slope } \\
\text { solar still }\end{array}$ & $2.012 \mathrm{~kg}$ \\
\hline \multirow[t]{2}{*}{4} & \multirow[t]{2}{*}{$\begin{array}{l}\text { (Vaithilingam } \\
\text { et al. 2021) }\end{array}$} & \multirow[t]{2}{*}{$\begin{array}{l}\text { Acrylic solar still with and } \\
\text { without copper fins }\end{array}$} & $\begin{array}{l}\text { - Acrylic solar still without } \\
\text { copper fins }\end{array}$ & $3.75 \mathrm{~kg} / \mathrm{m}^{2}$ \\
\hline & & & $\begin{array}{l}\text { - Acrylic solar still with } \\
\text { copper fins }\end{array}$ & $5.08 \mathrm{~kg} / \mathrm{m}^{2}$ \\
\hline \multirow[t]{3}{*}{5} & \multirow{3}{*}{$\begin{array}{l}\text { (Suraparaju et } \\
\text { al., 2021) }\end{array}$} & \multirow[t]{3}{*}{ Solar still using ball marbles } & - Sunny days & \multirow{2}{*}{$\begin{array}{l}2.950 \\
\mathrm{~kg} / \mathrm{m}^{2}\end{array}$} \\
\hline & & & \multirow[t]{2}{*}{ - Cloudy days } & \\
\hline & & & & $\begin{array}{l}2.150 \\
\mathrm{~kg} / \mathrm{m}^{2}\end{array}$ \\
\hline
\end{tabular}

$6 \quad$ (Suraparaju et al., 2021)

Single-slope solar still with PCM
- conventional still

- solar still with hollow finned absorber inserted in energy storage

- solar still with solid finned absorber inserted in energy storage

$7 \quad$ (Natarajan et al., 2021)
Solar still (SS) with low-cost and eco-friendly materials
- conventional still

- molasses powder

- rice husk

- saw dust

- bamboo straw

- banana leaf stem

- rice straw
$2.885 \mathrm{~L} / \mathrm{m}^{2}$

$4.085 \mathrm{~L} / \mathrm{m}^{2}$

$3.485 \mathrm{~L} / \mathrm{m}^{2}$

$2.250 \mathrm{~L} / \mathrm{m}^{2}$

$2.383 \mathrm{~L} / \mathrm{m}^{2}$

$2.467 \mathrm{~L} / \mathrm{m}^{2}$

$3.033 \mathrm{~L} / \mathrm{m}^{2}$

$2.700 \mathrm{~L} / \mathrm{m}^{2}$

$2.683 \mathrm{~L} / \mathrm{m}^{2}$

$3.367 \mathrm{~L} / \mathrm{m}^{2}$ 


\begin{tabular}{|c|c|c|c|c|}
\hline $\begin{array}{l}\text { Sl. } \\
\text { No. }\end{array}$ & Author name & Type of solar still & Enhancement techniques & Productivity \\
\hline \multirow[t]{3}{*}{8} & \multirow{3}{*}{$\begin{array}{l}\text { (Dhivagar et } \\
\text { al., 2021) }\end{array}$} & \multirow{3}{*}{$\begin{array}{l}\text { Solar still using block and } \\
\text { disc magnets }\end{array}$} & - conventional still & $2.15 \mathrm{~L} / \mathrm{m}^{2}$ \\
\hline & & & - still using block magnets & $3.15 \mathrm{~L} / \mathrm{m}^{2}$ \\
\hline & & & - still using disc magnets & $2.82 \mathrm{~L} / \mathrm{m}^{2}$ \\
\hline \multirow[t]{4}{*}{9} & \multirow{4}{*}{$\begin{array}{l}\text { (Balachandran } \\
\text { et al., 2021) }\end{array}$} & \multirow{4}{*}{$\begin{array}{l}\text { Solar still with and without } \\
\text { insulation }\end{array}$} & - conventional still & $1.93 \mathrm{~L} / \mathrm{m}^{2}$ \\
\hline & & & without insulation & $2.58 \mathrm{~L} / \mathrm{m}^{2}$ \\
\hline & & & $\begin{array}{l}\text { - still with polystyrene } \\
\text { insulation }\end{array}$ & $3.26 \mathrm{~L} / \mathrm{m}^{2}$ \\
\hline & & & - still with fibre insulation & \\
\hline \multirow[t]{2}{*}{10} & \multirow{2}{*}{$\begin{array}{l}\text { (Balachandran } \\
\text { et al., 2021) }\end{array}$} & \multirow{2}{*}{$\begin{array}{l}\text { Single slope novel stepped } \\
\text { absorbable plate solar stills }\end{array}$} & - conventional still & $2.47 \mathrm{~L} / \mathrm{m}^{2}$ \\
\hline & & & $\begin{array}{l}\text { - stepped absorbable plate } \\
\text { solar stills }\end{array}$ & $3.05 \mathrm{~L} / \mathrm{m}^{2}$ \\
\hline \multirow[t]{2}{*}{11} & \multirow[t]{2}{*}{ Present work } & \multirow{2}{*}{$\begin{array}{l}\text { Solar still with inbuilt } \\
\text { condenser and agitator }\end{array}$} & - conventional still & $2.444 \mathrm{~L} / \mathrm{m}^{2}$ \\
\hline & & & - SSICA & $4.856 \mathrm{~L} / \mathrm{m}^{2}$ \\
\hline
\end{tabular}

\section{Conclusion}

Conventional Solar Still (CSS) and Solar still with inbuilt condenser and agitator (SSICA) were compared. Introducing in-built condenser increased the condensation area for same evaporation area. Agitator increases evaporation rate by agitating basin water to increase its surface area of contact with surroundings. Both stills were fabricated and experimented at Ramco Institute of Technology, Rajapalayam, India $\left(9.4536^{\circ} \mathrm{N}, 77.5433^{\circ} \mathrm{E}\right)$ with a water depth of $10 \mathrm{~mm}$. Experiment was carried out under same ambient condition to assess the performance exactly. SSICA yields $4.856 \mathrm{~L} / \mathrm{m}^{2} /$ day distillate and CSS yields $2.444 \mathrm{~L} / \mathrm{m}^{2} /$ day. The improvised yield in SSICA was due to agitation effect and introduction of inbuilt condenser. Performance of SSICA and CSS were analyzed by comparing their energy and exergy efficiency. Energy analysis revealed that SSICA is $24.42 \%$ more efficient than CSS when considering solar PV area and $31.10 \%$ more efficient when excluding the solar PV area. Exergy efficiency of CSS is $2.04 \%$. The same for that of SSICA is $4.31 \%$ when solar PV area is included and $4.82 \%$ when solar PV area is excluded. Exergy analysis reveals that minimizing the exergy destruction in basin is having more scope to improve the efficiency of the still. Total daily exergy destruction of basin in SSICA and CSS were calculated to be $3044.68 \mathrm{~W} / \mathrm{m}^{2}$ and $3132.71 \mathrm{~W} / \mathrm{m}^{2}$ respectively. Exergy destruction of water and glass in CSS are $326.93 \mathrm{~W} / \mathrm{m}^{2}$ and $210.52 \mathrm{~W} / \mathrm{m}^{2}$ respectively and that of SSICA are 314.42 $\mathrm{W} / \mathrm{m}^{2}$ and $215.24 \mathrm{~W} / \mathrm{m}^{2}$ respectively. 


\section{Abbreviations}

$\mathrm{m}_{\mathrm{w}}=$ hourly distillate yield $(\mathrm{kg})$

$\tau_{g}=$ transmittance of the glass cover

$\tau_{\mathrm{w}}=$ transmittance of the saline water

$a_{b}=$ absorptivity of the basin

$a_{w}=$ absorptivity of saline water

$a_{g}=$ absorptivity of glass cover

$\mathrm{T}_{\mathrm{a}}=$ Ambient Temperature $(\mathrm{K})$

$T_{S}=$ Temperature of Sun $(K)$

$\mathrm{T}_{\mathrm{b}}=$ Basin Temperature $(\mathrm{K})$

$\mathrm{T}_{\mathrm{g}}=$ Glass Cover Temperature (K)

$\mathrm{I}_{\mathrm{t}}=$ Solar Intensity $\left(\mathrm{W} / \mathrm{m}^{2}\right)$

$h_{w}=$ convective heat transfer coefficient between basin and saline water $\left(W / m^{2} K\right)$

$h_{b}=$ convective heat transfer coefficient between basin and atmosphere $\left(W / m^{2} K\right)$

$h_{e, w-g}=$ evaporative heat transfer coefficient between water and inner glass cover $\left(W / m^{2} K\right)$

$h_{c, w-g}=$ convective heat transfer coefficient between water and inner glass cover $\left(\mathrm{W} / \mathrm{m}^{2} \mathrm{~K}\right)$

$h_{r, W-g}=$ radiative heat transfer coefficient between water and inner glass cover $\left(\mathrm{W} / \mathrm{m}^{2} \mathrm{~K}\right)$

$h_{c, g-a}=$ convective heat transfer coefficient between glass cover and atmosphere $\left(W / m^{2} K\right)$

$h_{r, g-a}=$ radiative heat transfer coefficient between glass cover and atmosphere $\left(\mathrm{W} / \mathrm{m}^{2} \mathrm{~K}\right)$

\section{Declarations}

Funding:

Not Applicable 
The authors declare that no funds, grants, or other support were received during the preparation of this manuscript.

\section{Competing Interests:}

Not Applicable

The authors have no relevant financial or non-financial interests to disclose.

\section{Authors Contributions:}

Arun Kumar - Carried out the experimentation for evaluating the performance of the system. Preparing the first draft of the manuscript

Kalidasa Murugavel - Contributed to the designing of system and experimentation. Reviewed and prepared the final draft of the manuscript.

\section{Ethical Approval:}

Not applicable

\section{Consent to participate:}

Not applicable

\section{Consent to Publish:}

Not applicable

\section{Availability of Data and Materials:}

Not applicable

\section{References}

1. Abdullah AS, Essa FA, Omara ZM, Rashid Y, Hadj-Taieb L, Abdelaziz GB, Kabeel AE (2019) Rotatingdrum solar still with enhanced evaporation and condensation techniques: Comprehensive study. Energ Convers Manage 199:112024

2. Amiri H, Aminy M, Lotfi M, Jafarbeglo B (2021) Energy and exergy analysis of a new solar still composed of parabolic trough collector with built-in solar still. Renew Energ 163:465-479

3. Attia MEH, Driss Z, Kabeel AE et al (2021) Phosphate bags as energy storage materials for enhancement of solar still performance. Environ Sci Pollut Res 28:21540-21552. https://doi.org/10.1007/s11356-020-12018-x 
4. Attia MEH, Kabeel AE, Bellila A et al (2021) A comparative energy and exergy efficiency study of hemispherical and single-slope solar stills. Environ Sci Pollut Res 28:35649-35659. https://doi.org/10.1007/s11356-021-13161-9

5. Balachandran GB, David PW, Alexander AB et al (2021) A relative study on energy and exergy analysis between conventional single slope and novel stepped absorbable plate solar stills. Environ Sci Pollut Res 28:57602-57618. https://doi.org/10.1007/s11356-021-14640-9

6. Balachandran GB, David PW, Radhakrishnan V et al (2021) Investigation on the performance enhancement of single-slope solar still using green fibre insulation derived from Artocarpus heterophyllus rags reinforced with Azadirachta indica gum. Environ Sci Pollut Res 28:32879-32890. https://doi.org/10.1007/s11356-021-13062-x

7. Dhivagar R, Mohanraj M, Deepanraj B et al (2021) Assessment of single slope solar still using block and disc magnets via productivity, economic and enviro-economic perspectives: A comparative study. Environ Sci Pollut Res. https://doi.org/10.1007/s11356-021-15565-z

8. Dubey M, Mishra DR (2021) Experimental analysis of double slope solar still augmented with dye, pebbles and metal chips. Environ Sci Pollut Res 28:22077-22090. https://doi.org/10.1007/s11356020-11869-8

9. Dumka P, Jain A, Mishra DR (2020) Energy, exergy and economic analysis of single slope conventional solar still augmented with an ultrasonic fogger and a cotton cloth. J Energy Storage 30:101541

10. Dumka P, Mishra DR (2018) Energy and exergy analysis of conventional and modified solar still integrated with sand bed earth: Study of heat and mass transfer. Desalination 437:15-25

11. El-Samadony YAF, Kabeel AE (2014) Theoretical estimation of the optimum glass cover water film cooling parameters combinations of a stepped solar still. Energy 68:744-750

12. Essa FA, Abdullah AS, Omara ZM (2020) Rotating discs solar still: New mechanism of desalination. J Clean Prod 275:123200

13. Iqbal A, Mahmoud MS, Sayed ET, Elsaid K, Abdelkareem MA, Alawadhi H, Olabi AG (2021) Evaluation of the nanofluid-assisted desalination through solar stills in the last decade. J Environ Manage 277:111415

14. Jobrane M, Kopmeier A, Kahn A, Cauchie H-M, Kharroubi A, Penny C (2021) Internal and external improvements of wick type solar stills in different configurations for drinking water production- $A$ review. Groundwater for Sustainable Development 100519

15. Kabeel AE, Abdelaziz GB, El-Said EMS (2019) Experimental investigation of a solar still with composite material heat storage: Energy, exergy and economic analysis. J Clean Prod 231:21-34

16. Kumar RA, Esakkimuthu G, Murugavel KK (2016) Performance enhancement of a single basin single slope solar still using agitation effect and external condenser. Desalination 399:198-202

17. Manokar AM, Murugavel KM, Esakkimuthu G (2014) Different parameters affecting the rate of evaporation and condensation on passive solar still - A review. Renew Sust Energ Rev 38:309-322 
18. Mevada D, Panchal H, Ahmadein M et al (2021) Investigation and performance analysis of solar still with energy storage materials: An energy- exergy efficiency analysis. Case Studies in Therm Eng 101687

19. Mohsenzadeh M, Aye L, Christopher $P$ (2021) A review on various designs for performance improvement of passive solar stills for remote areas. Sol Energy 228:594-611

20. Muftah AF, Alghoul MA, Fudholi A, Abdul-Majeed M, Sopian K (2014) Factors affecting basin type solar still productivity: A Review. Renew Sust Energ Rev 32:430-447

21. Natarajan SK, Suraparaju SK, Elavarasan RM et al (2021) An experimental study on eco-friendly and cost-effective natural materials for productivity enhancement of single slope solar still. Environ Sci Pollut Res. https://doi.org/10.1007/s11356-021-15764-8

22. Nayi KH, Modi KV (2018) Pyramid Solar Still: A Comprehensive Review. Renew Sust Energ Rev $81: 136-148$

23. Omara ZM, Abdullah AS, Dakrory T (2017) Improving the productivity of solar still by using water fan and wind turbine. Sol Energy 147:181-188

24. Patel SK, Modi KV (2020) Techniques to improve the performance of enhanced condensation area solar still: A critical review. J Clean Prod 268:122260

25. Prakash P, Velmurugan V (2015) Parameters influencing the productivity of solar stills - A review. Renew Sust Energ Rev 49:585-609

26. Sharshir SW, Eltawil MA, Algazzar AM, Sathyamurthy R, Kandeal AW (2020) Performance enhancement of stepped double slope solar still by using nanoparticles and linen wicks: Energy, exergy and economic analysis. Appl Therm Eng 174:115278

27. Sharshir SW, Peng G, Elsheikh AH, Edreis EMA, Eltawil MA, Abdelhamid T, Kabeel AE, Zang J, Yang N (2018) Energy and exergy analysis of solar stills with micro/nano particles: A comparative study. Energ Convers Manage 177:363-375

28. Sharshir SW, Yang N, Peng G, Kabeel AE (2016) Factors affecting solar stills productivity and improvement techniques: A detailed review. Appl Therm Eng 100:267-284

29. Shoeibi S, Rahbar N, Esfahlani AA, Kargarsharifabad H (2021) A review of techniques for simultaneous enhancement of evaporation and condensation rates in solar stills. Sol Energy 225:666-693

30. Singh SK, Kaushik SC, Tyagi VV, Tyagi SK (2021) Comparative Performance and parametric study of solar still: A review. Sustain Energy Technol Assess 47:101541

31. Suraparaju SK, Natarajan SK (2021) Productivity enhancement of single-slope solar still with novel bottom finned absorber basin inserted in phase change material (PCM): techno-economic and enviroeconomic analysis. Environ Sci Pollut Res 28:45985-46006

32. Suraparaju SK, Ramasamy D, Natarajan SK (2021) Augmentation of freshwater productivity in a single slope solar still using ball marbles. Environ Sci Pollut Res. https://doi.org/10.1007/s11356021-15117-5 
33. Vaithilingam S, Muthu V, Athikesavan MM, Afsal A, Sathyamurthy R (2021) Energy and exergy analysis of conventional acrylic solar still with and without copper fins. Environ Sci Pollut Res. https://doi.org/10.1007/s11356-021-16124-2

34. Younis M, Habchi C, Ahmad MN, Ghali K (2020) Optimization of the performance of a solar still assisted by a rotating drum with a rough surface. Sol Energy 211:847-865

35. Yousef MS, Hassan H, Ahmed M, Ookawara S (2017) Energy and exergy analysis of single slope passive solar still under Egyptian climate conditions. Enrgy Proced 141:18-23

Figures
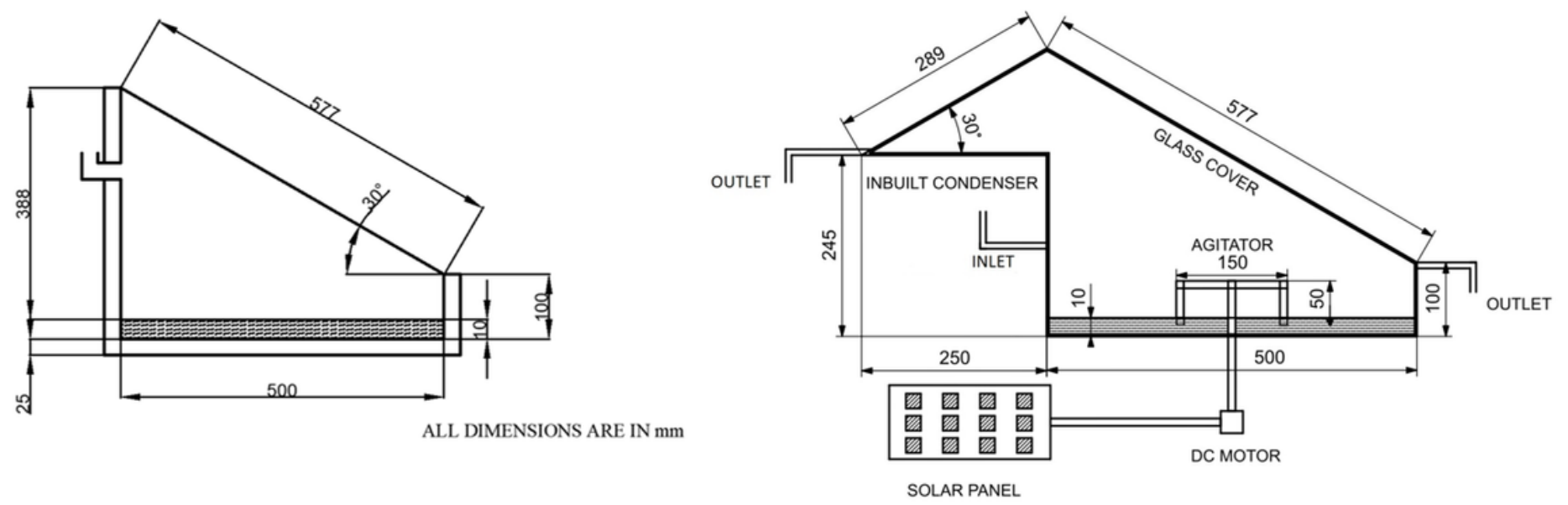

ALL DIMENSIONS ARE IN MM

Figure 1

a Design of CSS

b Design of SSICA 


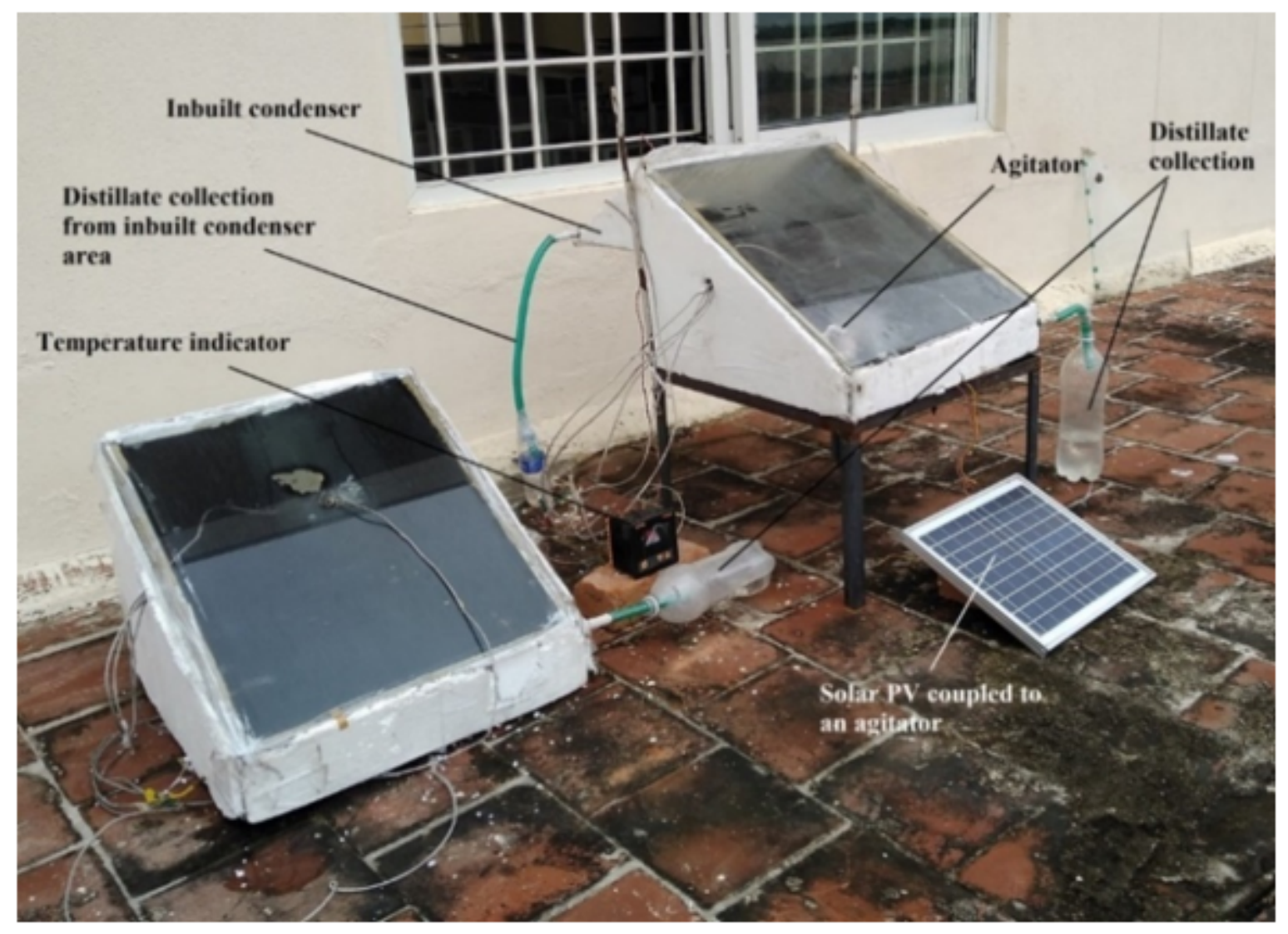

Figure 2

Experimental setup - CSS and SSICA 


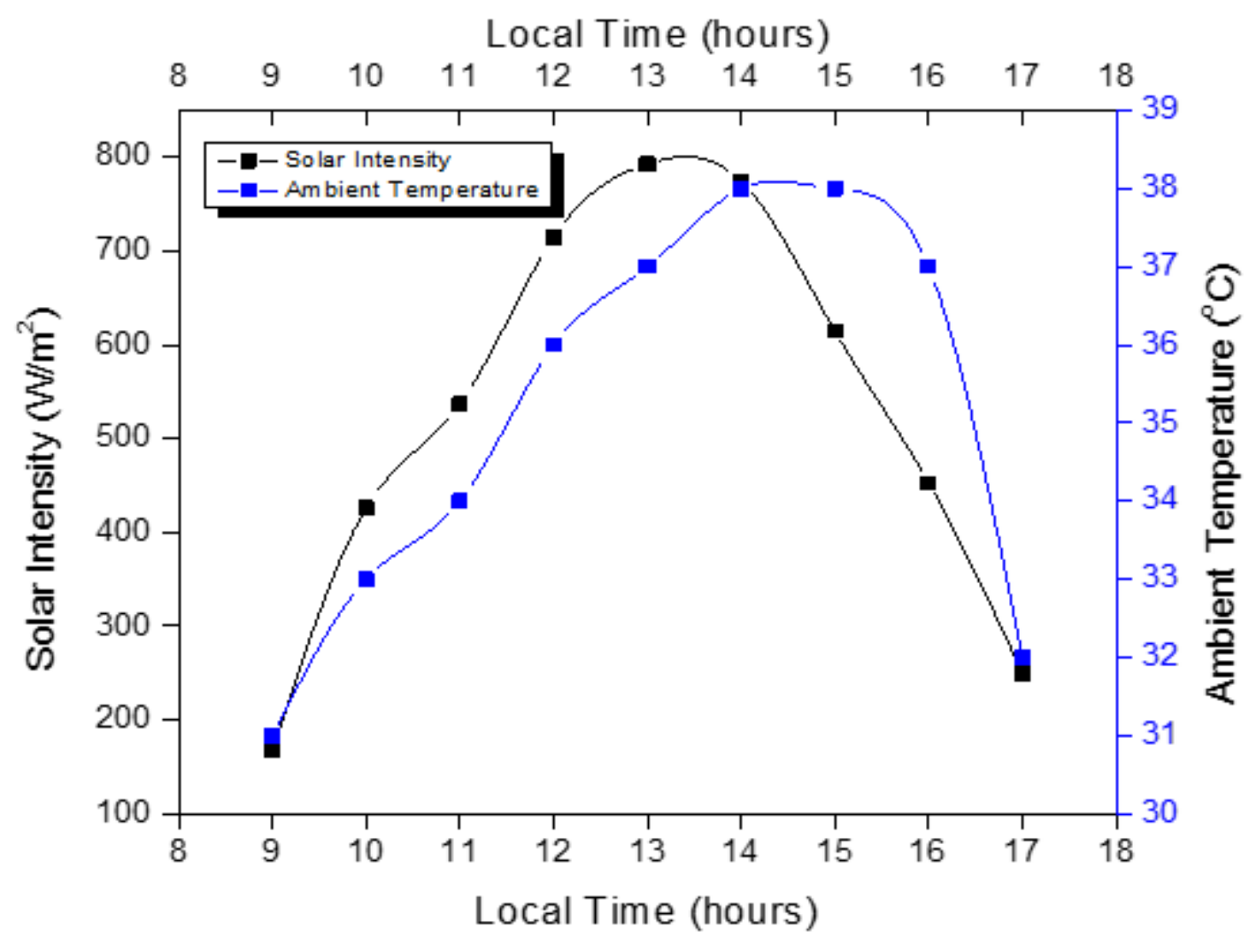

Figure 3

Trend of Solar Intensity, Ambient Temperature with time

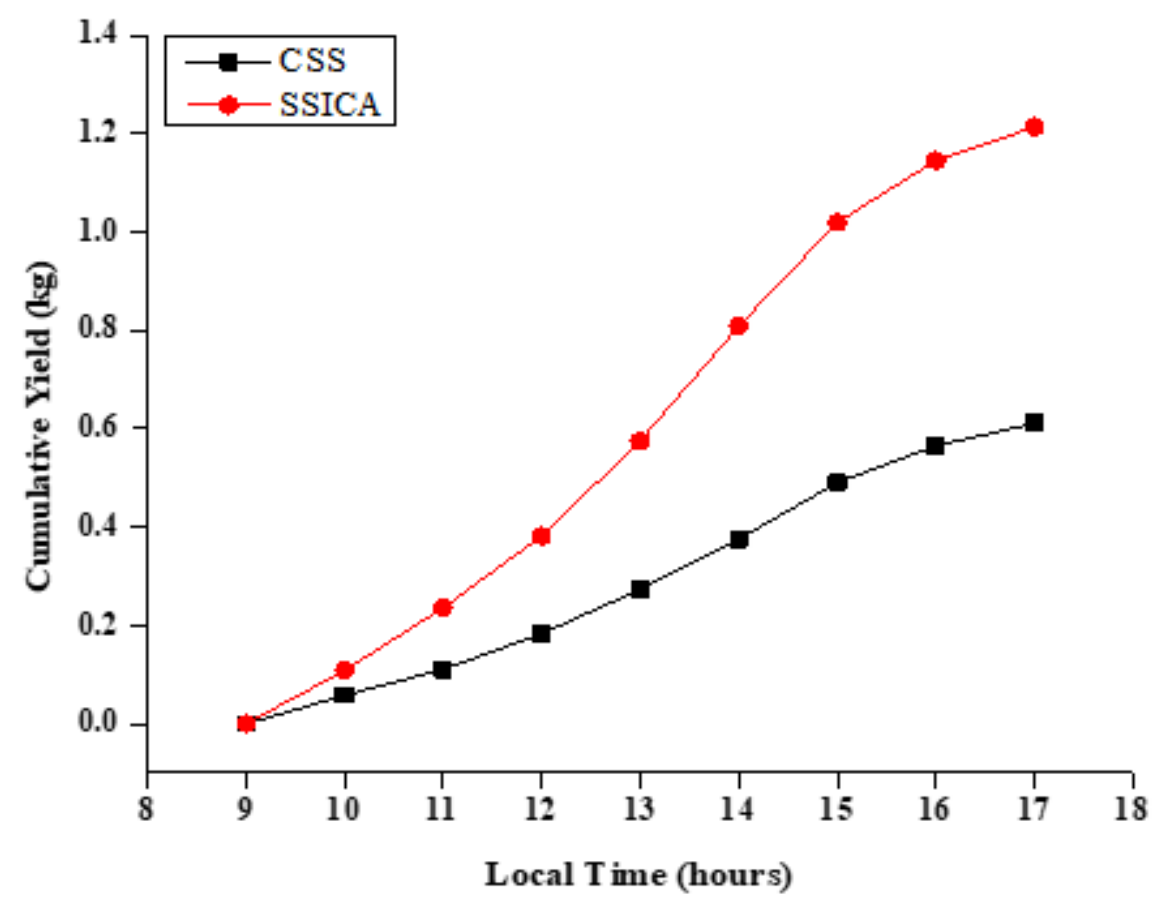

Figure 4 


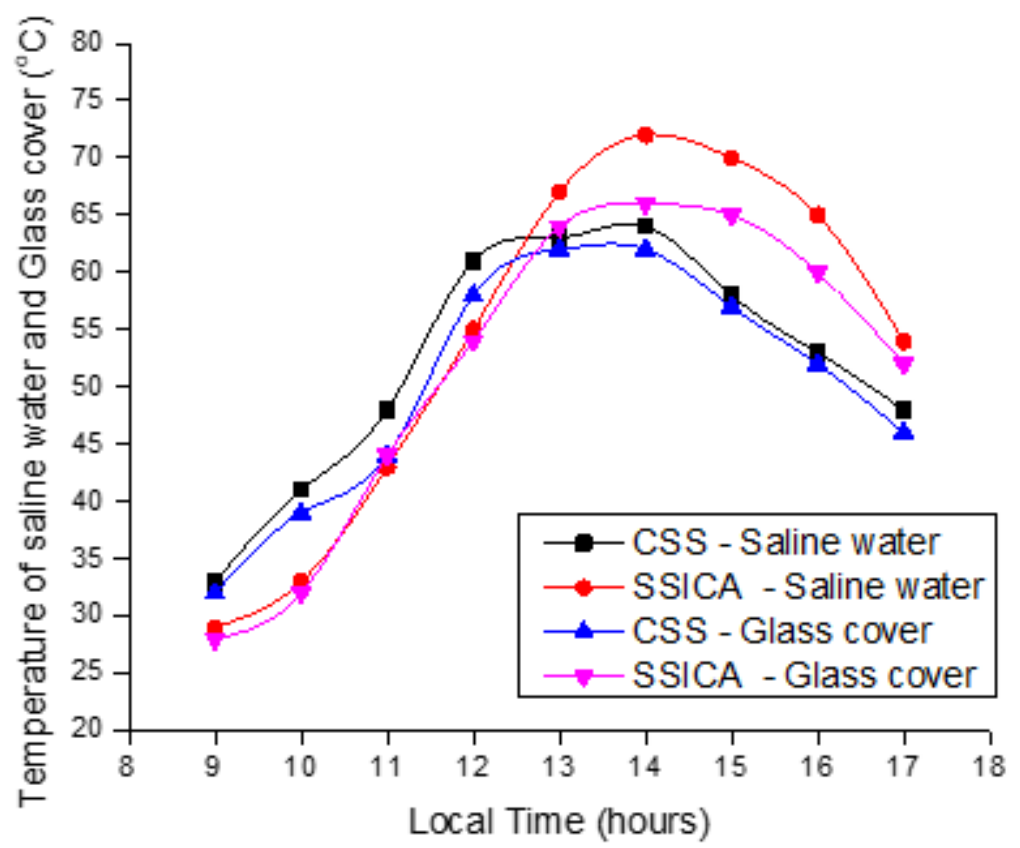

Figure 5

Trend in saline water and glass cover temperatures of CSS and SSICA along time

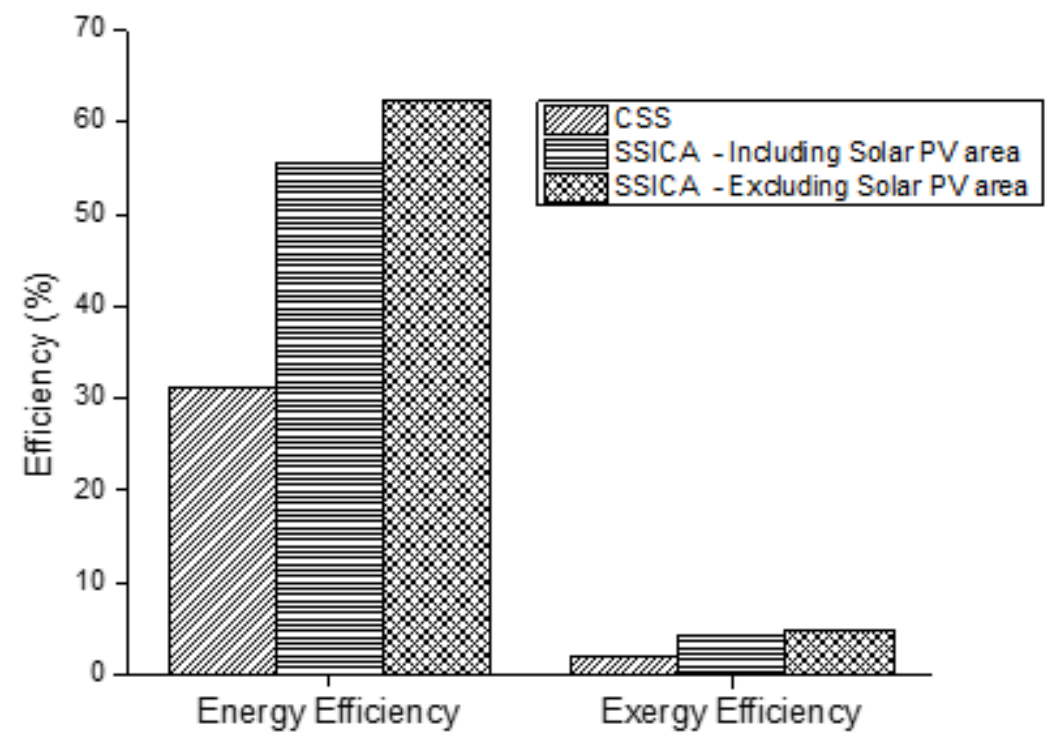

Figure 6

Energy, exergy efficiency of CSS, SSICA including and excluding Solar PV area 


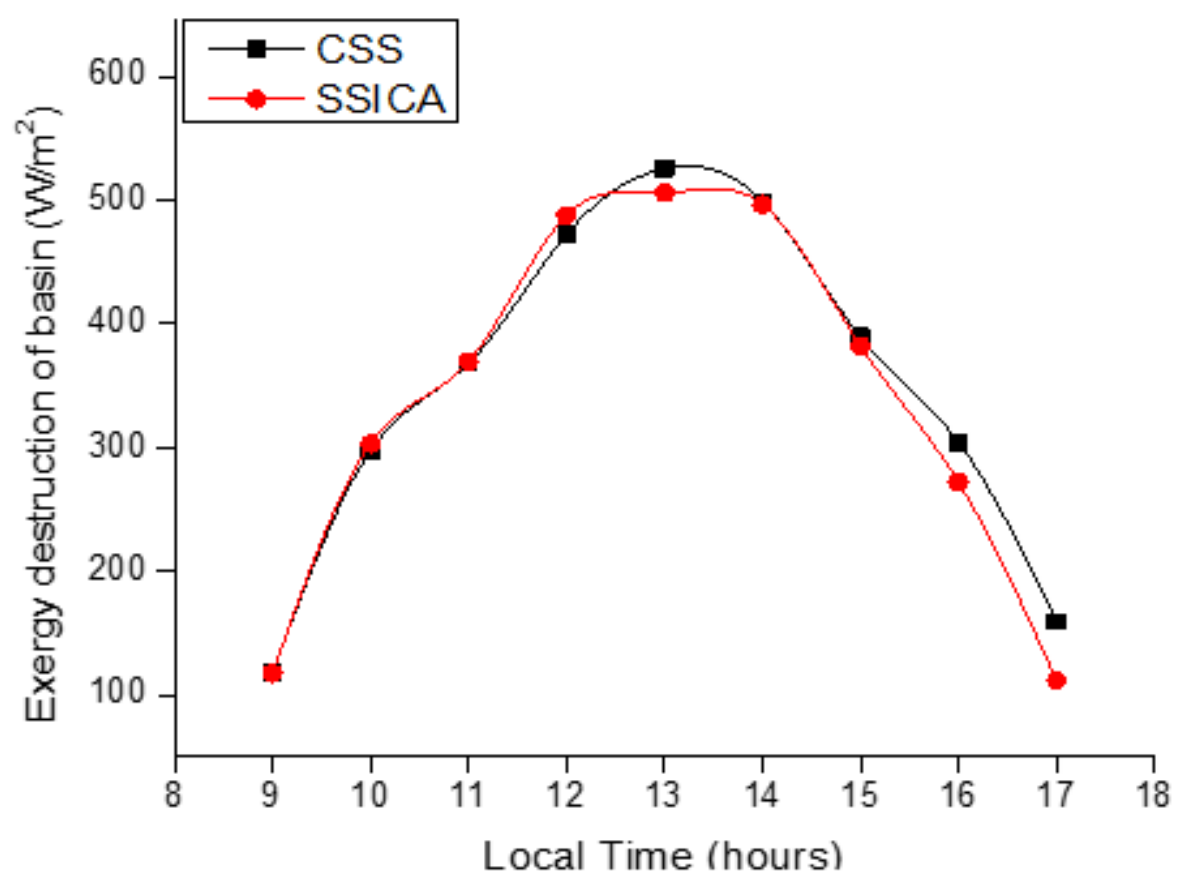

Figure 7

Trend in Basin exergy destruction of CSS and SSICA along the day

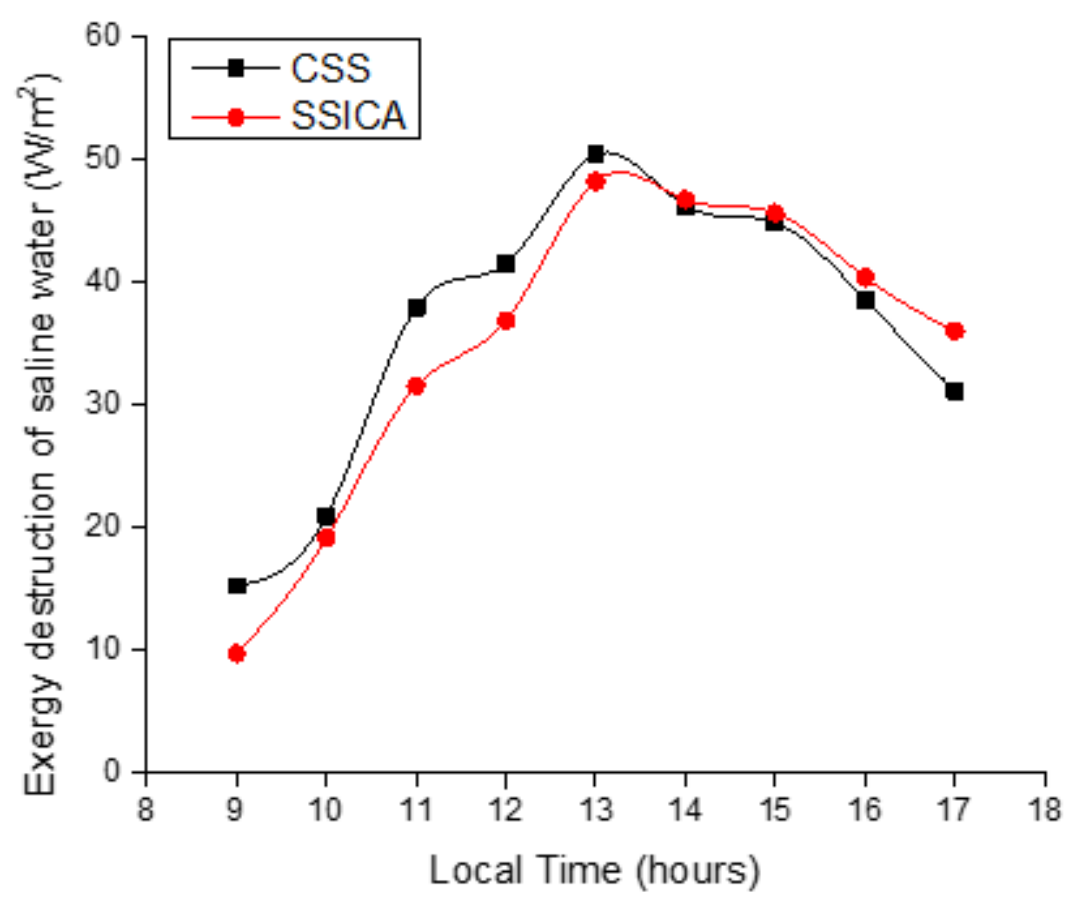

Figure 8

Trend in saline water exergy destruction of CSS and SSICA along the day 


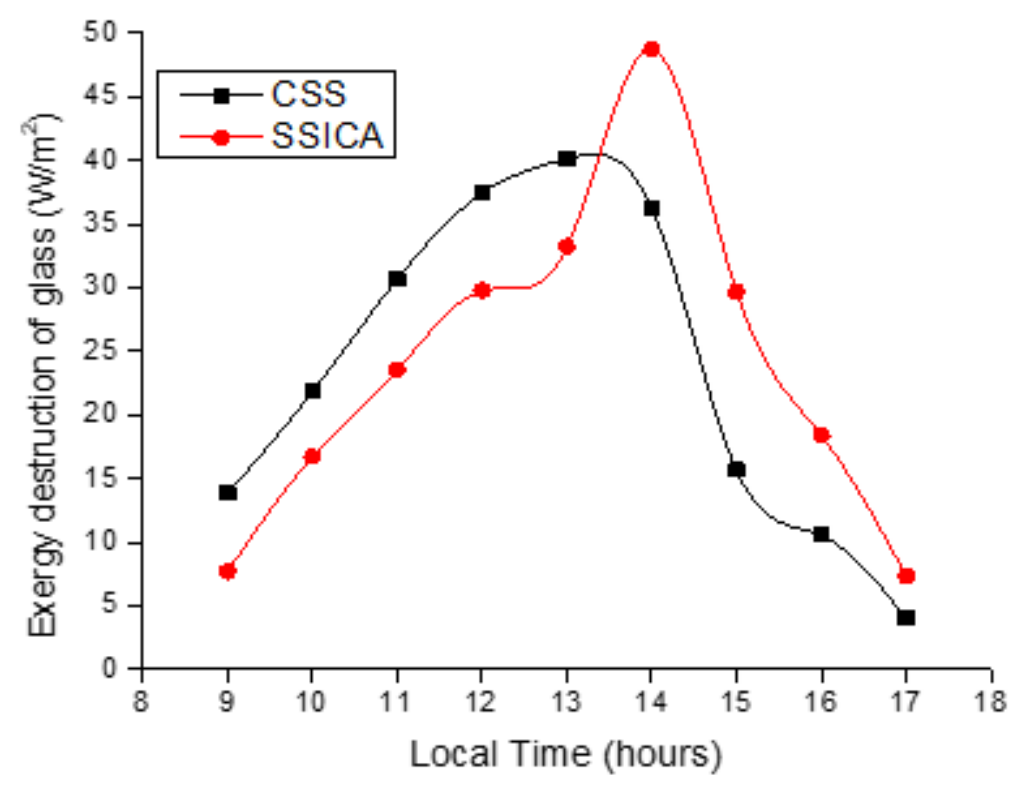

Figure 9

Trend in glass exergy destruction of CSS and SSICA along the day

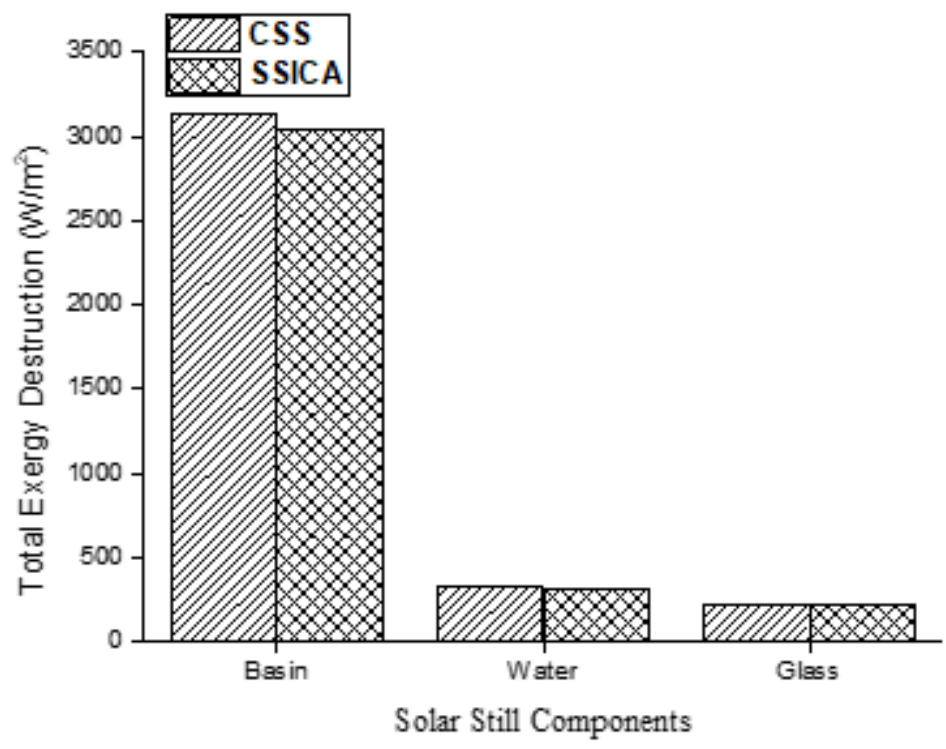

Figure 10

Total exergy destruction of solar still components 